\title{
Anaemia and serum protein alteration in patients with pressure ulcers
}

\author{
U Fuoco, G Scivoletto, A Pace, VU Vona and V Castellano \\ IRCCS, Ospedale S. Lucia-Rome, Italy
}

\begin{abstract}
The presence of anaemia and serum protein alteration frequently makes the treatment of pressure ulcers more difficult. Several haemato-chemical parameters were observed in 40 patients with sacral pressure ulcers in order to determine the pathogenesis of these complications. All of the patients showed mild-moderate anaemia with low serum iron and normal or increased ferritin and hypoproteinemia with hypoalbuminemia. Our results suggest that both anaemia and serum protein alteration depend on the chronic inflammatory state due to the presence of pressure ulcers. Both anaemia and hypoproteinemia disappeared after pressure ulcer healing.

A correct diagnosis is important for the treatment. Iron therapy is useless and potentially dangerous (iatrogenic haemochromatosis) since anaemia is the result of the inability to use iron stores and not iron deficiency. The treatment of serum protein alterations should be based on a dietary therapy rich in protein and calories; the administration of albumin should be reduced, since albumin is low in essential amino-acids and too expensive; albumin administration should be limited to cases with severe hypoproteinemia and oedema.
\end{abstract}

Keywords: pressure ulcers; anaemia; serum protein alteration; chronic inflammatory state

\section{Introduction}

Pressure ulcers are complications which frequently occur in patients who have been bedridden for a long time. They worsen the clinical picture and require a long period in bed for the patient.

Anaemia and serum protein alteration in patients with a pressure ulcer are considered unfavourable to the healing of the ulcer. The anaemia, which is usually mild, mimics iron deficiency and is often treated with iron therapy. ${ }^{1-3}$ The hypoalbuminemia, which is considered secondary to loss of plasma from the ulcer (in the form of sweat), is treated with plasma and albumin transfusions in the more severe cases.

Several haemato-chemical parameters from a group of patients who came to our hospital with a pressure ulcer were studied and compared with those of the same group of patients after sore healing to determine the pathogenesis of the anaemia and the serum protein alteration.

\section{Patients and methods}

Forty patients, 17 males and 23 females, mean age 53.5 years, were studied (group A). Twenty-nine patients were affected by spinal cord injury (all in the postacute phase), seven by hemiparesis and four by a broken

Correspondence: G Scivoletto, v.le Jonio 87, 00141 Rome, Italy femur. All suffered from a sacral pressure ulcer which had persisted for more than 30 days (from 30 days to 6 months, mean time 2.7 months). The severity of the ulcers were determined by the NPUAP classification: ${ }^{4}$ all patients were diagnosed as phase IV ulcers. At the time of examination the ulcers were clean and did not show signs of severe infection. The ulcer areas were measured and expressed in $\mathrm{cm}^{2}$ (minimum $12.5 \mathrm{~cm}^{2}$, maximum $78 \mathrm{~cm}^{2}$, mean area $25 \mathrm{~cm}^{2}$ ). Patients with neoplastic pathologies, chronic inflammatory and infectious diseases, collagenopathies and pre-existing anaemias (treated with iron therapy or blood transfusion) were not considered for the study. All the patients underwent radiological examinations that did not show any signs of osteomyelitis.

The patients underwent the following laboratory examinations: electroproteinogram, Erythrocyte Sedimentation rate (ESR), C-Reactive Protein (CRP), blood cell count with formula, serum iron, transferrinemia with percent saturation and ferritinema.

The findings were compared with those obtained from the same patients $30-60$ days after sore healing (group B).

The severity of anaemia was determined according to Lee et al classification. ${ }^{5}$

Statistical analysis was carried out by means of the Wilcoxon Scores Test for non-parametric data. Decubitus ulcer area was correlated with degree of anaemia and serum protein alteration by means of Spearman's rank correlation coefficient $(r)$. 


\section{Results}

\section{Blood cell count}

Twenty-nine patients in group A showed mild anaemia (haemoglobin $9-11 \mathrm{~g} / \mathrm{dl}$ ) and 11 moderate anaemia (haemoglobin $7-8 \mathrm{~g} / \mathrm{dl}$ ). The following statistically significant differences were found between groups A and B: red cell count $(3,225,000$ vs 4,250,000 $P<0.001)$; haemoglobin $(9.45$ vs $12.35 \mathrm{~g} / \mathrm{dl} P<0.001)$; hematocrit (31.09 vs 38.4\% $P<0.006)$; MCV (87.2 vs $91.79 \mathrm{fl}$. $P<0.01)$; serum iron $(48.4$ vs $75 \mathrm{mcg} / \mathrm{dl} \quad P<0.007)$; ferritin (291.8 vs $190.4 \mathrm{mcg} / \mathrm{dl} \quad P<0.001)$; transferrin (154.9 vs $203.2 \mathrm{mcg} / \mathrm{dl} P<0.001)$ transferrin saturation (25.8 vs $28.7 \% \quad P<0.03$ ). There was no statistically significant correlation between degree of anaemia and decubitus ulcer areas $(r=0.085)$.

\section{Inflammatory indexes}

All patients in group A showed statistically significant higher ESR (85.3 vs $27 \mathrm{mM} / \mathrm{h} P<0.001)$, CRP (3.4 vs $0.67 \mathrm{mg} / \mathrm{dl} P<0.001)$ and white cell counts $(8,550 \mathrm{vs}$ $5,800 / \mathrm{mmc} P<0.01)$ than patients in group B.

\section{Serum proteins}

The following statistically significant alterations were found in group A patients: total hypoproteinemia (5.45 vs $6.3 \mathrm{~g} / \mathrm{dl} P<0.03)$, decreased albumin $(2.73$ vs $3.65 \mathrm{~g} /$ dl $P<0.001)$ with inverse albumin/globulin ratio $(0.88$ vs $1.43 P<0.002)$, increased alfa 1 globulins $(0.26$ vs $0.15 \mathrm{~g} / \mathrm{dl} P<0.03)$ and increased total globulins $(3.09$ vs $2.55 \mathrm{~g} / \mathrm{dl} \quad P<0.08)$. No differences were found between the two groups for alfa2, beta and gamma globulins. No statistically significant correlation was found between serum protein alteration and decubitus ulcer rates $(r=0.091)$.

\section{Discussion and conclusion}

Our results suggest that patients afflicted with pressure ulcers show mild anaemia in $70 \%$ of cases and moderate anaemia in the remaining $30 \%$, according to Lee et al classification. ${ }^{5}$ The coexistence of anaemia (with increased ferritin values and reduced transferrin) and inflammatory status (high ESR, CRP and white cell counts) demonstrate that our patients' anaemias fall into the 'anaemias of chronic disorders', as already seen by other authors. ${ }^{3,6}$ This form of anaemia, found in many chronic diseases such as chronic inflammatory processes, neoplasms and rheumatoid arthritis is characterised by normal iron stores in the reticuloendothelial system (RES) $)^{7,8}$ and is probably due to the inability to use the iron stored in the RES. ${ }^{9}$ When diagnosing this kind of anaemia it is extremely important to measure ferritin and transferrin with percent saturation in order to differentiate it from irondeficiency anaemia. The latter is characterised by ferritin values lower than $15 \mathrm{mcg} / \mathrm{dl}$ (which indicates reduced iron stores in the RES) and increased total transferrin (with reduced percent saturation) since the hepatic synthesis of this protein is triggered by iron deficiency and inhibited by infectious and toxic conditions. ${ }^{10-13}$

Serum protein showed the following alterations: hypoalbuminemia with inverse albumin/globulin ration, increased level of globulins and total hypoproteinemia. The pathogenesis of hypoalbuminemia is due to three possible factors: (A) protein loss from the ulcer; (b) decreased hepatic synthesis; (c) protein hypercatabolism; (B) and (C) may be secondary to the chronic inflammatory state. ${ }^{11,14}$ We would like to suggest that the hypoalbuminemia found in these patients may be due primarily to a decreased hepatic synthesis as a consequence of the chronic inflammatory state. ${ }^{15}$ The inflammatory state inhibits hepatic synthesis and reduces the amount of amino-acids available for the synthesis of other protein. ${ }^{11}$ In our opinion this hypothesis is supported by the following data:

(1) all patients showed higher inflammatory indexes when compared to the control group;

(2) presence of chronic disorder/type anaemia;

(3) decreased albumin levels and increased globulin;

(4) increased synthesis of protein such as alfa 1 globulins and ferritin and concurrent decreased levels of albumin and transferrin;

(5) no statistically significant relation was found between ulcer size and severity of hypoalbuminemia and anaemia.

If these alterations are due to loss of plasma from the ulcer or to accelerated protein catabolism, a decrease in all protein fractions could be expected. Obviously when the ulcer involves a large area of the skin, the amount of protein lost can be significant and be an important cause of protein alteration.

A correct diagnosis is very important for determining the kind of treatment needed.

With regard to anaemia therapy, if the amount of iron storage is satisfactory, it is not advisable to give iron; this is not only useless, but also potentially dangerous (iatrogenic haemochromatosis). ${ }^{14}$ The anaemia in these patients does not require any treatment since, as we demonstrated, it regresses with the disappearance of the decubitus. Since the anaemia develops slowly and rarely becomes severe, blood transfusions are not needed. ${ }^{16}$ Recent studies have shown that the administration of erythropoietin may prove effective in the treatment of this type of anaemia. $^{17}$

With regard to serum protein alteration, our results show that the administration of albumin to patients to compensate for protein loss and help heal the ulcer should be avoided and substituted with parenteral therapy or a diet rich in calories and protein to reduce the negative effect of the hypercatabolism.

(1) the main cause of hypoalbuminemia is not protein loss from the ulcer but reduced hepatic synthesis secondary to the chronic inflammatory state; 
(2) hypoalbuminemia does not worsen over time, but remains moderate and tends to regress with the disappearance of the ulcer;

(3) many authors disagree with the use of albumin to accelerate wound cicatrization; ${ }^{18}$

(4) the administration of albumin to make up for dietary deficiencies is not advisable because it is poor in the essential amino-acids, such as tryptophan, and is very expensive.

In our study only five patients required albumin administration. Their hypoproteinemia had caused diffused oedemas. We suggest therefore that albumin should be supplied only in a few cases of severe hypoalbuminemia.

\section{References}

1 The Medical Letter on Drugs and Therapeutics. Year XIX (29th, 1990), n. 812.

2 Williams CM, Lines CM, McKay EC. Iron and zinc status in multiple sclerosis patients with bedsores. Europ J Clin Nutrition 1988; 42 (4): 321 - 328.

3 Perkash A, Brown M. Anemia in patients with traumatic spinal cord injury. J Am Paraplegia Soc 1986; 9 (1-2): $10-15$.

4 National Pressure Ulcer Advisory Panel. Decubitus 1989; 2: 24.

5 Lee RG, Wintrobe MM, Bunn FH. Anemia sidropenica e le anemie sideroblastiche. In: Isselbacher KJ et al. (eds). 'Harrison's Principi di medicina interna'. Piccin: Padova, vol. 2: pp. 2087 2091.
6 Hirsch GH, Menard MR, Anton HA. Anemia after traumatic spinal cord injury. Arch Phys Med Rehab 1991; 72 (3): 195-201.

7 Cartwright GE. The anemia of chronic disorders. Semin Hematol 1966; 3: $351-355$.

8 Roberts FD, Hagerdon AB, Slocumb C, Owen LA. Evaluation of the anemia of rheumatoid arthritis. Blood 1963; 21: 470-476.

9 Bunn FH. Anemia associata a malattie sistemiche croniche. In: Isselbacher KJ et al. (eds). 'Harrison's Principi di medicina interna', Piccin: Padova, vol. 2: pp. 2109-2112.

10 Andus T, Bauer J, Gerok W. Effects of cytokines on the liver. Hepatology 1991; 13: $364-368$.

11 Jarnum S, Lassen NA. Albumin and transferrin metabolism in infections and toxic diseases. Scan J Clin Lab Invest 1961; 13: $357-361$.

12 Sehgal PB. Interleukin-6: a regulator of plasma protein gene expression in hepatic and non-hepatic tissues. Mol Biol Med 1990; 7: $117-125$.

13 Umeda T. Pathophysiological studies on iron metabolism. Transferrin (siderophillin) metabolism in infection. J Kyushu Hematol Soc 1965; 15: $153-160$.

14 Corso F. Manuale di patologia clinica. Second edition. Masson: Milano, 1986; pp. 75-88.

15 Fuoco $U$ et al. Patogenesi della disprotidemia in pazienti con ulcera da decubito. Proceedings of XXI Congresso Nazionale S.I.M.F.E.R., October 10-13 1993, vol. 2: pp. 517-518.

16 Fuoco U et al. Pathogenesi della anemia in pazienti con ulcera da decubito. Proceedings of XXI Congresso Nazionale S.I.M.F.E.R., October 10-13 1993, vol. 2: pp. 519-520.

17 Turba RM, Lewis VI, Green D. Decubitus ulcer anemia: response to erythropoietin. Arch Phys Med Rehab 1992; 75 (5): 498 - 500.

18 Waldman TA, Gordon RS, Rosse W. Studies on the metabolism of serum protein and lipids in patients with analbuminemia. $A m J$ Med 1984; 37: $960-968$. 